\title{
Effect of Leadership Style, Work Environment and Financial Compensation On Em- ployee Performance (Study at PT Bank X Area, South Jakarta)
}

\author{
Aziz Setyawan \\ STIE Indonesia Banking School \\ azizsetyawan96@gmail.com
}

\section{Wasi Bagasworo}

STIE Indonesia Banking School

wasi.bagasworo@ibs.ac.id

\begin{abstract}
Indonesian banking conditions are currently growing rapidly, in line with the development of the Indonesian economy and era. This is reflected by the level of profit which is quite good in line with the improving level of banking efficiency and strong banking capital. This study aims to analyze the performance of permanent employees at Bank X Area South Jakarta. This study uses variables of leadership style, work environment, and financial compensation to analyze the effect on employee performance. Data collection method used in this research is primary data by distributing questionnaire to Bank X Area South Jakarta permanent employee. Data collected by 100 respondents by using the Structural Equation Modeling (SEM) analysis. The summary of the result from this research are: 1) Leadership Style does not have a positive and significant influence on employee performance, 2) Work Environment has a negative effect on employee performance, 3) Financial Compensation have a positive and significant effect on employee performance at PT Bank X Area South Jakarta
\end{abstract}

Keywords: Leadership Style, Work Environment, Financial Compensation, Employee Performance

\begin{abstract}
Abstrak
Kondisi perbankan Indonesia saat ini berkembang pesat, seiring dengan perkembangan ekonomi dan era Indonesia. Hal ini tercermin dari tingkat keuntungan yang cukup baik seiring dengan meningkatnya tingkat efisiensi perbankan dan permodalan perbankan yang kuat. Penelitian ini bertujuan untuk menganalisis kinerja karyawan tetap di Bank X Area Jakarta Selatan. Penelitian ini menggunakan variabel gaya kepemimpinan, lingkungan kerja, dan kompensasi finansial untuk menganalisis pengaruhnya terhadap kinerja karyawan. Metode pengumpulan data yang digunakan dalam penelitian ini adalah data primer dengan menyebarkan kuesioner kepada karyawan tetap Bank X Area Jakarta Selatan. Data dikumpulkan oleh 100 responden dengan menggunakan analisis Structural Equation Modeling (SEM). Ringkasan hasil dari penelitian ini adalah: 1) Gaya Kepemimpinan tidak memiliki pengaruh positif dan signifikan terhadap kinerja karyawan, 2) Lingkungan Kerja berpengaruh negatif terhadap kinerja karyawan, 3) Kompensasi Keuangan berpengaruh positif dan signifikan terhadap karyawan kinerja di PT Bank X Area Jakarta Selatan.
\end{abstract}

Kata Kunci: Gaya Kepemimpinan, Lingkungan Kerja, Kompensasi Keuangan, Kinerja Karyawan

\section{Introduction}

Banking according to Law No. 10 of 1998 is a business entity that collects funds from the community in the form of deposits and distributes them to the public in the form of loans or other forms in order to improve the lives of the people at large. (www.bi.go.id).

The Indonesian banking industry is currently improving, the condition of commercial banks in the third quarter of 2017 increased compared to the same period in 2016. This was reflected in the fairly good level of profit / profit (profitability) in line with the improvement in banking efficiency and strong banking capital. Commercial bank assets grew by $10.59 \%$, up from the same period in 2016 of $5.18 \%$. This increase was driven in part by increased growth in deposits (Third Party Funds) and increased capital. Based on the asset component side, lending also grew better than in 2016. Based on bank groups, the largest increase in nominal assets was found in BUSN (National Private Commercial Banks) Foreign Exchange which grew $13.67 \%$ (yoy), Non-Foreign Exchange BUSN and KCBA (Office Foreign Bank Branches) experienced a decline in assets in line with the decline in deposits in this group. The decrease in assets in the 
KCBA group was also influenced by the integration of one bank in the KCBA group into the Foreign Exchange BUSN group. (www.ojk.go.id).

The development in the Indonesian banking industry is inseparable from the performance of the employees of each company. According to Aguinis (2013), the effectiveness of individual performance in the alignment of organizational strategic goals has a direct effect on improving the performance of an organization. In an era of increasingly fierce competition, the performance of employees is required to continue to increase. One step to maintain or improve employee performance can be done by evaluating employee performance and carrying out a series of improvements to always improve the quality of employees, so the company grows and excels in facing competition (Riyadi, 2011).

\section{Theoretical Framework and Hypothesis De- velopment}

\section{Theoretical Framework}

Noe et al (2018), high-performance work systems are organizations where technology, organizational structure, people, and processes work together seamlessly to provide organizations with excellence in a competitive environment. According to Dessler (2017), performance is a continuous process for identifying, measuring, and developing individual or team performance and aligning their performance with organizational goals. Performance is a continuous process, identifying, measuring, and developing individual and team performance in aligning it with the organization's strategic goals (Aguinis, 2013),

Pierce \& Newstrom (2011), leadership is the interaction between two or more members of a group or organization which often involves structuring or restructuring the situation of perceptions of members in the organization. According to Daft (2011), leadership is a relationship that affects between leaders and followers who want change and tangible results that reflect shared goals. Leadership as the ability to influence a group towards achieving a vision or set of goals (Robbins \& Judge, 2017).

According to Schultz (2006), the work environment is defined as a condition related to the characteristics of the workplace to the behavior and attitudes of employees where it relates to the occurrence of psychological changes because of things experienced in the work or in certain circumstances that must continue attention by the organization which includes boredom of work, monotonous work and fatigue. According to Sedarmayanti (2009), the work environment can be in the form of physical conditions of the office which include lighting, air temperature, etc. that can improve the conducive atmosphere and morale and influence employee performance (Bachtiar, 2015).

Dessler (2017), financial compensation is any form of payment or reward given to employees and arises from being hired by the employee, the compensation program reflects the organization's efforts to retain its human resources. According to Noe et al (2018), compensation is all of the gifts given to employees in return for their services. According to Daft (2000), compensation refers to all forms of remuneration for money and all goods or commodities used as remuneration for money to employees.

\section{Hypothesis Development}

A good leader can be a role model for his subordinates so that it will create enthusiasm and enthusiasm for employees to produce good performance. Conversely, if the leader cannot set a good example for his subordinates, it will adversely affect employee performance (Sukmawati, 2008). According to Dulbert (2014), leadership contributes relatively large and very significant to the improvement of employee performance in an organization, so that in organizational development programs should be more directed at developing organizational leadership styles. Hackman \& Wageman (2007), emphasizes that the key to leadership is an attractive arrangement of the direction of team work that is challenging, energizing team members and producing strong collective motivation to perform well.

Based on this explanation, the following hypothesis is proposed:

H1: The leadership style has a positive influence on employee performance

The work environment is outside institutions or forces that have the potential to affect the performance of employees and organizations (Robbins \& Judge, 2017). According to Bachtiar, 2015 there is the influence of the work environment on employee performance, this illustrates that with a good work environment, the better employee performance will be created, the existence of a work environment is very important, because the existence of a conducive work environment can directly affect employees in improve the performance. Chughtai \& Buckley (2008), states that there will be a significant positive correlation between work environment and performance.

Based on this explanation, the following hypothesis is proposed:

H2: The work environment has a positive influence on employee performance 


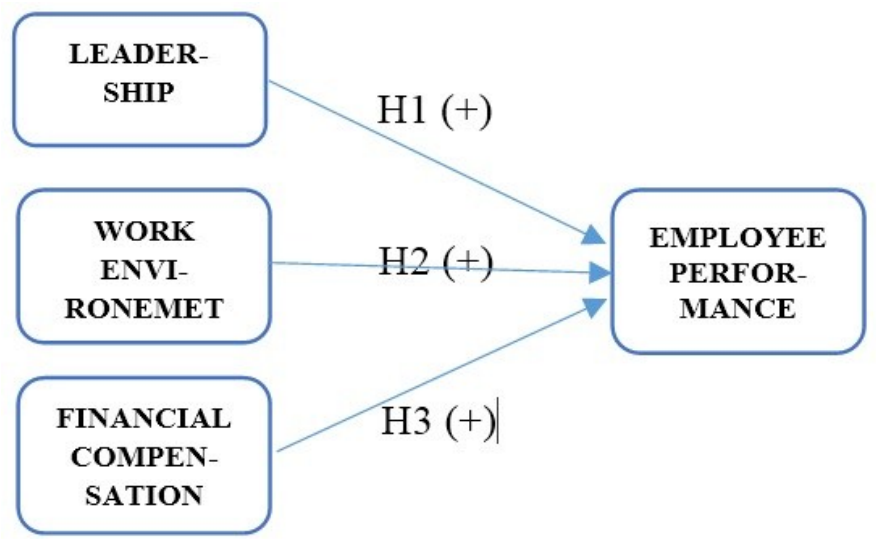

Figure 1. Research Model

Wayne (2002) states that financial compensation includes direct cash, indirect payments in the form of employee benefits, and incentives to motivate employees to work hard to achieve higher performance (Sudibya \& Utama, 2012). Limão \& Saggi (2008), explain financial compensation must be given to create a sense of justice for employees for the performance that has been given. According to Garbers \& Konradt (2013), financial compensation or financial incentives provided by companies will always be positively related to performance. Jenkins et al (1998), stated that financial compensation or financial incentives can provide motivation for workers to improve performance.

Based on this explanation, the following hypothesis is proposed:

H3: Financial compensation has a positive influence on employee performance

\section{Research Method}

The method used in this research is quantitative descriptive method. Descriptive method is a research method used to describe problems that occur in the present or in progress, aiming to describe everything that happened as it should when the research was conducted(Margareta,2013).

The object examined in this study is permanent employees with staff level who have worked at least 6 months and have passed the trial period in the Business Support and Customer Banking section at the South Jakarta Bank X Area. Bank X is a BUMN (State-Owned Enterprise) banking, whose main activities are collecting funds from the community in the form of deposits and distributing them to the community in the form of loans or other forms in order to improve the living standards of the people (www.bi.go.id).

The sampling technique in this study was purposive sampling where researchers determined sampling by specifying specific characteristics that were in accordance with the objectives of the study so that they were expected to answer the research problems. However, to obtain a valid calculation result for the sample, the sample size guidelines depend on the number of indicators multiplied by 5 to 10 (Hair et al, 2010). Based on these calculations, then in this study can be seen the number of samples as follows:

$$
\begin{aligned}
& \mathrm{n}=\mathrm{i} \times \text { (scale } 5 \text { to } 10) \\
& \mathrm{n}=20 \times 5=100 \text { (respondents) }
\end{aligned}
$$

This study took the number of respondents as many as 100 people.

The data processing method used in this study is the SEM method. SEM method or Structural Equation Modeling in processing data using analysis of covariance structures to explain casuality between constructs. SEM method has a limitation that is only presenting one relationship of the dependent variable with independent variables. The main advantage of SEM is that some dependent relationships are interrelated so that they can be estimated together and it can present unobserved concepts or latent variables (Cooper \& Schindler, 2011).

\section{Result, Discussion, and Managerial Implica- tion}

The research respondents consisted of 100 people who were majority in the age of 21-29 years and the last level of education was S1. The expenditure of the majority of respondents is more than 3,000,000 rupiah who work more than 4 years and respondents are dominated by women.

SEM analysis can be continued if the results of model identification show that the model belongs to the Over Identified category or the degree of freedom value from the research model. The results of AMOS output in this study indicate a degree of freedom value of 150 . This indicates that the model belongs to the Over Identified category because it has a positive degree of freedom value and the data can proceed to the next stage.

The Goodness of Fit research results show that 
Table 1. Output Regression

\begin{tabular}{cccccc}
\hline Hipotesis & Estimasi & S.E. & C.R. & p-value & Conclusion \\
\hline Leadership Style - Employee Performance & $-0,433$ & 0,088 & $-4,922$ & $* * *$ & Supported by data \\
Work Environment - Employee Performance & $-0,085$ & 0,103 & $-0,827$ & 0,408 & Not supported by data \\
$\begin{array}{c}\text { Financial Compensation - Employee Perfor- } \\
\text { mance }\end{array}$ & 1,217 & 0,192 & 6,349 & $* * *$ & Supported by data \\
\hline
\end{tabular}

there are three GOF sizes, namely CINM / DF that has Good Fit, CFI shows Poor Fit, and RMSEA that has a Poor Fit. The overall model indicates that overall data is quite fit with the SEM model.

The results of hypothesis conclusions can be determined by looking at the estimated values and $p$. If the estimated value in the results of the analysis shows a positive value and $p$ value $<0.05$, the hypothesis proves to be significant and supported by data. However, if the estimated value shows a negative result and the value of $p>0.05$, the hypothesis does not prove significant and is not supported by data. The following table describes the results of data analysis from the overall model.

\section{Effect of Leadership Style on Employee Perfor- mance}

The results of this study indicate that the leadership style proved to have a negative and significant effect on employee performance. The results of this analysis do not support the Sukmawati (2008) study, which says that there are positive and significant effects partially between leadership variables and employee performance, this shows that the better leadership in a company will increasingly influence the performance of its employees. Other studies say that leadership is the key to performing well (Hackman \& Wageman, (2007).

Leadership style that does not affect employee performance means that leaders are not always the key or factors that can affect employee performance. In accordance with the phenomenon that occurred at Bank X, the leadership of the business support and customer banking division at Bank $X$ had a poor performance. But what happened despite having a poorly performing leader, the performance of employees at Bank X proved to be good and outstanding. Where at the beginning of 2018 the e-channel section, which was from the business support and customer banking division, was in first place as a team / division with the best e-channel services in all of Indonesia.

\section{Effect of Work Environment on Employee Per- formance}

The results of this study indicate that the work environment proved to have no effect on employee performance. The estimation results in this study are not in accordance with the research model and are not supported by data, so it can be said that the hypothesis has no influence. The results of this analysis do not support the theory of Robbins \& Judge (2017), who said that the work environment is outside institutions or forces that have the potential to affect the performance of employees and organizations.

Employees' perceptions of the work environment at Bank X Area in South Jakarta do not directly support employee performance. Every employee has different perceptions and often must be accepted as a risk for the company. Therefore, Bank X must provide solutions to minimize these risks, including increasing employee perceptions of the work environment both physically and nonphysically.

\section{Effect of Financial Compensation on Employee Performance}

The results showed that financial compensation proved to have a positive and significant influence on employee performance. The results of this study are consistent with Wayne's (2002) research, financial compensation includes direct cash, indirect payments in the form of employee benefits, and incentives to motivate employees to work hard to achieve higher performance (Sudibya \& Utama, 2012).

Bank $\mathrm{X}$ is a company that prioritizes the welfare of its employees, where a lot of compensation is given such as salaries, benefits, incentives, bonuses, and others. Based on the profile of respondents of monthly expenditures of Bank employees $\mathrm{X}>$ Rp. 3,000,001 amounting to 52\%, meaning that in terms of financially Bank $\mathrm{X}$ employees are quite prosperous. Financial compensation provided can affect employee performance. According to Jenkins et al (1998), stating financial compensation or financial incentives can provide motivation for workers to improve performance.

\section{Managerial Implications}

This study aims to determine and analyze the 
extent to which the intentions of Bank X Area employees in South Jakarta are influenced by variables of leadership style, work environment, financial compensation, and employee performance. The results of this analysis state that financial compensation has a positive effect and has a significant effect on employee performance, and a leadership style has a negative effect and has a significant effect on employee performance.

Based on the results of the analysis, the average value of the financial compensation variable is quite good. These results are proven by an average value of 4.47. Based on the three indicators of financial compensation there is one indicator that has a value below the average of the other indicators, namely in KF1 regarding satisfaction with the salary given by the company with a value of 4.39 . This shows that Bank X employees choose a scale that is low enough for the indicator. The results of the questionnaire prove that Bank $\mathrm{X}$ employees are quite amenable to the salary provided by the company. Thus, the authors suggest that companies implement a fair payroll system in accordance with employee contributions to workload. The company can also provide awards in the form of benefits such as bonuses, overtime wages, performance allowances, THR, working period incentives, leave allowances, etc., so that employee perceptions of financial compensation can be higher, which in turn, will improve the performance of Bank X employees.

Based on the results of the analysis, the average value of the leadership style variable is quite good. These results are proven by an average value of 4.73. Based on 4 indicators of leadership style there is one indicator that has a value below the average of the other indicators, namely in GK1 which states that "I work well because I am inspired by the leader" has a value of 4.46. This shows that employees at Bank $X$ are quite inspired by their leaders to work well. Based on the profile of respondents, the majority of employees at Bank X 52\% are generation $\mathrm{Y}$ with the age range of 21-29 years. According to Suryadi (2015), the characteristics of generation $\mathrm{Y}$ are they have a strong sense of caring, new technology, like to try, be active, have high creativity, are not afraid of change, have brilliant, smart, and reliable ideas. Based on this understanding it means that generation $\mathrm{Y}$ employees have high enthusiasm and desire to develop even though sometimes their leaders are not so good, but they will continue to strive to be more productive in their company. The research conducted by Lita Mucharom, Human Capital Management Coat (2015), shows that generation $\mathrm{Y}$ is a person who works based on creativity, and looks for a more relaxed work environment, they are very technominded or have more use of gadgets, and they want to always be different and dominate the world of work (Suryadi, 2015). The author recommends that the company should conduct a review for leaders regarding the leadership style that is applied to their subordinates so that employee perceptions of the leadership become higher and employees can work better because they get inspiration from the leadership.

\section{Conclusion, Suggestion, and Limitations Conclusion}

The results of the analysis used the SEM method by showing from 3 hypotheses, 1 hypothesis proved to have a positive and significant effect, 1 hypothesis had a negative and significant effect, and 1 hypothesis proved to have a negative and insignificant effect. In testing, it can be concluded that:

1. Variables of leadership style are proven to have a negative and significant effect on employee performance

2. Work environment variables proved to have a negative and not significant effect on Employee Performance

3. Variable financial compensation proved to have a positive and significant effect on employee performance.

\section{Suggestion}

The results of conclusions on researchers are supported by the data obtained so that it can be a suggestion for the future for PT Bank X to improve the performance of employees and companies. Suggestions that can be given to PT Bank X and further research are as follows:

\section{PT Bank X}

a. The author recommends that companies implement a fair payroll system in accordance with employee contributions to workload. The company can also provide awards in the form of benefits such as bonuses, overtime wages, performance allowances, THR, working period incentives, leave allowances, etc., so that employee perceptions of financial compensation can be higher, which in turn, will improve the performance of Bank X employees .

b. The author recommends that the company should conduct a review for leaders regarding the leadership style that is applied to their subordinates so that employee perceptions of the leadership become higher and employees can work 
better because they get inspiration from the leadership.

\section{For further research}

a. Future research is expected to do better research, given the banking industry is currently growing. Researchers suggest that further research can develop financial compensation variables to be broader on non-financial compensation variables.

b. The object of the study is expected to be more extensive in its area, not only limited to one particular company or agency, for example the respondents studied in one city or one province.

\section{References}

Aguinis, Herman (2013). Performance Management (5th ed.) United States: Pearson Education

Bachtiar, D. (2015). Management Analysis Journal. Pengaruh Motivasi Dan Lingkungan Kerja Terhadap Kinerja Karyawan, 4(3), 212-218.

Chughtai, A. ., \& Buckley, F. (2008). Work Engagement and its Relationship with State and Trait Trust: A Conceptual Analysis. Journal of Chemical Information and Modeling, 53 (9), 1689-1699. https://doi.org/10.1017/ CBO9781107415324.004

Cooper, D. R., \& Schindler, P. S. (2011). Business Research Methods (11th ed). New York: New York: McGraw-Hill Higher Education; New York : McGraw-Hill Higher Education, 2011.

Daft Richard L. (2011). Leadership (5th ed.). United States: South-Western.

Daft, Richard L. (2000). Management (6th ed.). United States: South-Western.

Dessler, G. (2017). Human Resource Management (15th ed.). United States: Pearson Education.

Dulbert, Biatna T., (2014). Analisis faktor gaya kepemimpinan dan faktor etos kerja terhadap kinerja pegawai pada organisasi yang telah menerapkan SNI 19-9001-2001.

Garbers, Y., \& Konradt U., (2013). The effect of financial incentives on performance: A quantitative review of individual and team-based financial incentives. 87(1), 102-137. https:// doi.org/10.1111/joop.12039.

Hackman, J. R., \& Wageman, R. (2007). Asking the right questions about leadership: Discussion and conclusions. American Psychologist, 62(1), 43-47. https://doi.org/10.1037/0003066X.62.1.43

Hair, J. F., Black, W. C., Babin, B. J., \& Anderson, R. E. (2010). Multivariate Data Analisis: A global perspective. Analysis.

Handaru A., Utomo T., Sudiarditha K. (2013). Pengaruh Lingkungan Kerja, Kompensasi dan Komitmen Organisasi Terhadap Kepuasan Kerja Karyawan di RS "X". Jurnal Riset Manajemen Sains Indonesia (JRMSI), Vol 4, No., 116-135.

Handoyo, A. W., \& Setiawan, R. (2017). Pengaruh Employee Engagement Terhadap Kinerja Karyawan Pada PT . Tirta Rejeki Dewata, 5 (1), 1-8.

Jenkins, G. D., Mitra, A., Gupta, N., \& Shaw, J. D. (1998). Are financial incentives related to performance? A meta-analytic review of empirical research. 5(83). 777-787.

Kalkavan, S., \& Katrinli, A. (2014). The Effect Of Managerial Coaching Behaviors On The Employees Perception Of The Job Satisfaction, Organizational Commitment, And Job Performance: Case Study On Insurance Industry In Turkey. Journal Procedia - Sosial And Behavioral Sciences 150, 1137-1147.

Leonardo, E., \& Andreani, F. (2015). Pengaruh Pemberian Kompensasi Terhadap Kinerja Karyawan Pada Pt. Kopanitia. Agora, 3(2), 3 -6 .

Limão, N., \& Saggi, K. (2008). Tariff retaliation versus financial compensation in the enforcement of international trade agreements. Journal of International Economics, 76(1), 48-60. https://doi.org/10.1016/j.jinteco.2008.03.005

Noe, Raymond A., John R. Hollenbeck, Barry G., Patrick M. Wight., (2018). Fundamentals of Human Resource Management (7th ed.) New York : McGraw-Hill Education.

Pierce, Jon L., \& Newstrom John, W., (2011). Leader and The Leadership Process (6th ed.) Singapore: McGraw-Hill Education.

Pramudio, A., (2010). Analisis Faktor-Faktor Yang Mempengaruhi Kinerja Dosen Negeri Pada Kopertis Wilayah V Yogyakarta, 1-11.

Render, B., J., Heizer, Munson, C., (2016). Operation Management (10th ed.). Pearson Education.

Riyadi, S. (2011). Pengaruh Kompensasi Finansial, Gaya Kepemimpinan, dan Motivasi Kerja. Jurnal Manajemen Dan Kewirausahaan, 13 (1), 40-45. https://doi.org/10.9744/ jmk.13.1.40-45

Robbins, \& Judge, T. A. (2017). Organizational Behavior (7th ed.). United States: Pearson Education.

Schultz, D., \& Schultz, S E., (2006). Psychology \& Work Today (9th ed.) New Jersey : Pearson Education. Inc. 
Sudibya, I. G. A., \& Utama, I. W. M. (2012). Pegawai Di Lingkungan Kantor Dinas Pekerjaan Umum. Manajemen, Strategi Bisnis, Dan Kewirausahaan, 6(2), 173-184.

Sukmawati, F., (2008). Pengaruh kepemimpinan, lingkungan kerja fisik, dan kompensasi terhadap kinerja karyawan di PT Pertamina (Persero) UPMS III Terminal transit utama Balongan, Indramayu, Vol (2), 145-158. ISBN: 0095042814.

Suryadi, B. (2015). Generasi Y: Karakteristik, Masalah, dan Peran Konselor. 8(1). http:// repository.uinjkt.ac.id/dspace/ handle/123456789/34351. 